\title{
Energy Efficiency Building Code for Commercial Buildings in Sri Lanka
}

\author{
Final Draft
}

\section{Prepared for Ceylon Electricity Board}

\author{
Prepared by
}

Lawrence Berkeley National Laboratory, Berkeley California USA and Dessau Soprin, Montreal Quebec, Canada

September 2000 


\section{Acknowledgements}

This Energy Efficiency Building Code for Commercial Buildings in Sri Lanka was developed with the support of the World Bank. The project was initiated by Prof. Nimal de Silva, Chairman Urban Development Authority and P.A.M. Deraniyagala, Chairman Ceylon Electricity Board, to whom a debt of gratitude is owed for their guidance. The project was managed by the CEB Demand Side Management Branch: M.S. Jayalath (Deputy General Manager), K.K.U.B. Adikaram (Project Manager) and D.G.K. Ranasinghe. The Project Consultants were Econoler International (Canada), Lawrence Berkeley National Laboratory (USA), and Infotechs I/D/E/A/S (Sri Lanka), with Louis-Philippe Lavoie as Team Leader. The Steering Committee members were D.C. Wijeratne (Chair), Prof. Lal Balasooriya, M. Zubair, W.J.L.S. Fernando, Prasanna Silva, M.S. Jayalath \& B.B. Perera. Substantial expert guidance and assistance was provided by professionals who served as Technical Subcommittee members: Ventilation and Air Conditioning: Wijitha Perera, C.L.E. Koelmeyer, J.O. Yatawara; Lighting: Sharmila Dhanapala, S. Ranasinghe, Noel Joseph; Electric Power and Distribution: Ranil Seneratna, D.B. Yatawara, D.G.R. Fernando; Building Envelope: Dr. Samitha Manawadu; Jaliya Kumarasinghe, Arch. Mahinda Withanaarachchi \& Arch. Harsha Fernando Service Water Heating: K.D.C.E. Wickramaratne, Lakshman Jayasuriya, Parakrama Jayasinghe. The following individuals from LBNL performed technical analysis and authored the code: John Busch, Steve Greenberg, Francis Rubinstein, Andrea Denver, Esther Rawner, Ellen Franconi, Joe Huang, and Danielle Neils. Logistical support was provided by Irani Oluka Mayadunne and B.K.D.S. Samarasinghe. 


\section{Table of Contents}

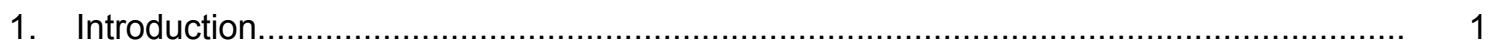

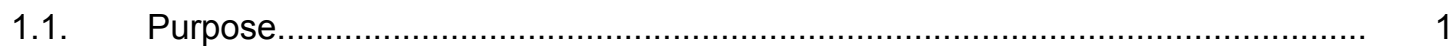

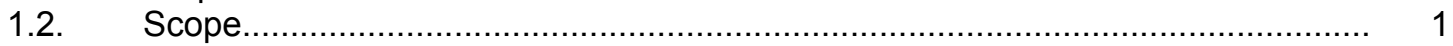

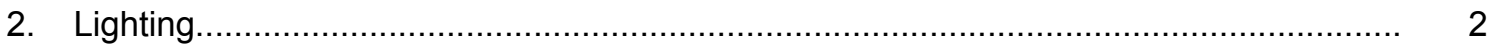

2.1. General Principles of Energy Efficient Lighting Practice.................................... 2

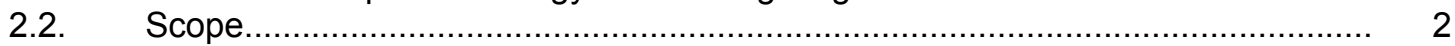

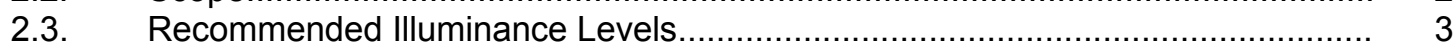

2.4. Lighting Equipment Efficiency Levels.......................................................... 5

2.5. Maximum Allowable Power for Illumination Systems...................................... 7

2.6. Building Exterior Lighting Power.................................................................... 8

2.7. Lighting Controls.................................................................................... 8

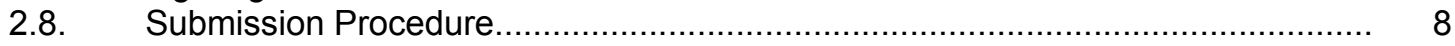

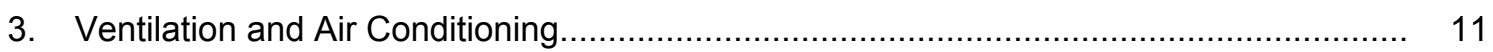

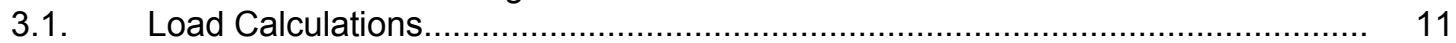

3.2. System and Equipment Sizing............................................................... 11

3.3. Fan System Design Criteria.................................................................. 11

3.4. Pumping System Design Criteria............................................................ 12

3.5. Separate Air Distribution Systems........................................................... 13

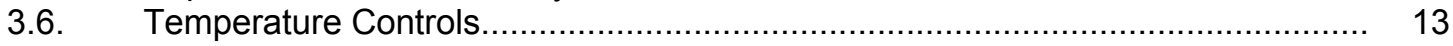

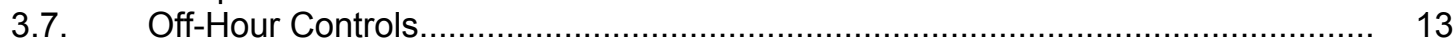

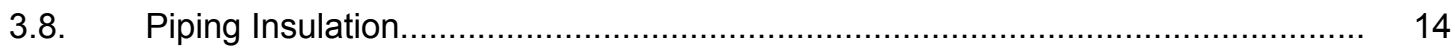

3.9. Air Handling System Insulation.............................................................. 15

3.10. Air Handling System Ducts................................................................. 16

3.11. AC Equipment.............................................................................. 17

3.12. Testing, Adjusting, Balancing and Commissioning......................................... 19

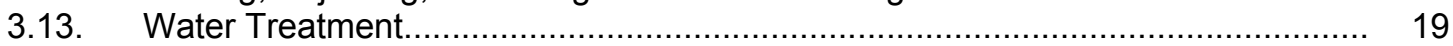

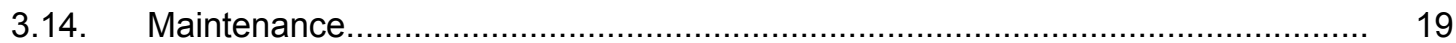

3.15. Submission Procedure ..................................................................... 20

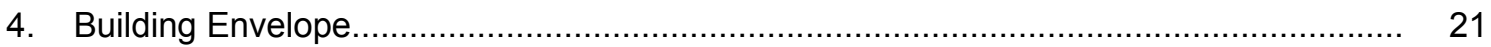

4.1. General Principles of Energy Efficient Envelope Design.................................. 21

4.2. System Performance Criteria for Exterior Walls.......................................... 21

4.3. Shading Coefficient................................................................................ 22

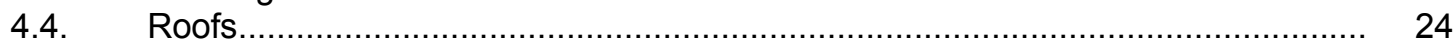

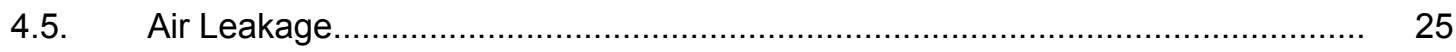

4.6. Submission Procedure ......................................................................... 25

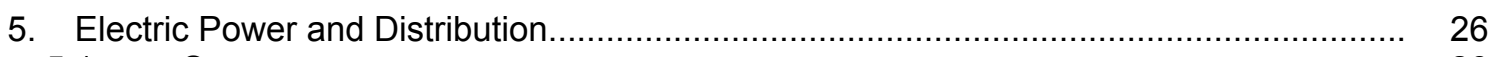

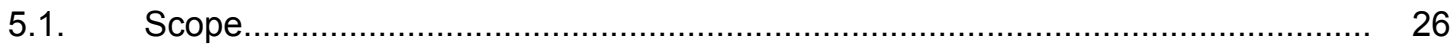

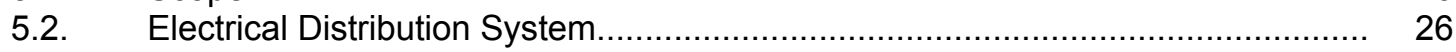

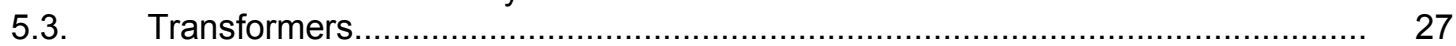

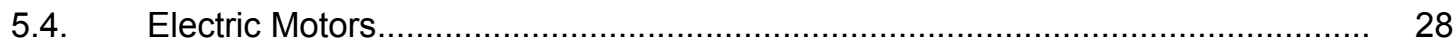

5.5. Submission Procedure $\quad$...................................................................... 30

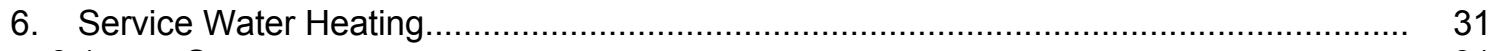

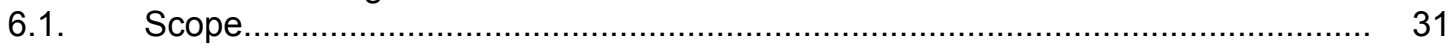

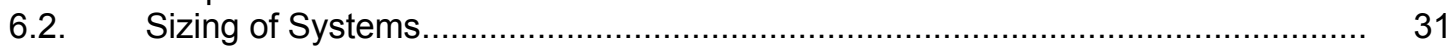

6.3. Water Heating Equipment Efficiency..................................................... 31

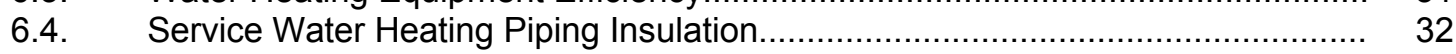

6.5. Service Water Heating System Controls................................................... 32

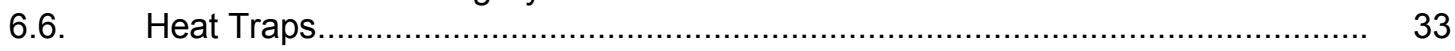

6.7. Submission Procedure ….................................................................. 33 


\section{List of Tables}

Table 2-1. Recommended Illuminance Levels and Glare Indices....................... 4

Table 2-2. $\quad$ Minimum Lamp Efficacy Linear Fluorescent Lamps......................... 5

Table 2-3. Minimum Lamp Efficacy Integral-Type Compact Fluorescent Lamps.. 5

Table 2-4. Minimum Lamp Efficacy Modular-Type Compact Fluorescent Lamps. 5

Table 2-5. Maximum Allowed Ballast Loss for Linear Fluorescent Lamps........... 6

Table 2-6. $\quad$ Incandescent Lamp- Minimum Lamp Efficacy................................... 6

Table 2-7. HID Lamp - Minimum Lamp Efficacy \& Maximum Allowed Ballast

Loss....................................................................................... 6

Table 2-8. $\quad$ Maximum Allowed Lighting Power Density....................................... 7

Table 2-9. $\quad$ Maximum Allowed Lighting Power for Building Exteriors.................... 8

Table 2-10. $\quad$ Maximum Allowed Lighting Power for Roads/Grounds....................... 8

Table 2-11. Power Credits for Certain Types of Lighting Controls........................ 10

Table 2-12. Power Credits for Automatic Daylighting Controls............................ 10

Table 3-1. Piping Insulation.................................................................... 15

Table 3-2. Minimum Duct Seal Level........................................................... 17

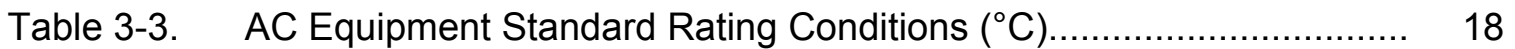

Table 3-4. Minimum Efficiencies for AC Equipment........................................ 18

Table 4-1. Solar Correction Factors (CF) (dimensionless) ............................. 21

Table 4-2. Shading Coefficient (SC) for Horizontal Overhang Projections............ 23

Table 4-3. Shading Coefficient (SC) for Vertical Side-Fin Projections................. 23

Table 4-4. Shading Coefficient (SC) for Horizontal \& Vertical "Egg-Crate" Projections.................................................................... 24

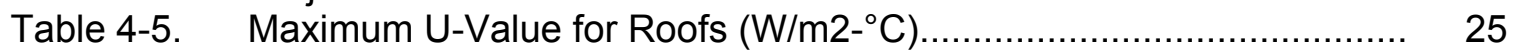

Table 5-1. $\quad 11 \mathrm{kV}$ Transformer, 3-phase, oil immersed.................................... 27

Table 5-2. $\quad 33$ kV Transformer, 3-phase, oil immersed........................................ 27

Table 5-3. Minimum Efficiencies for Three-Phase Induction Motors................... 30

Table 6-1. Minimum Energy Efficiency of Water Heating Equipment................... 31

Table 6-2. Minimum Pipe Insulation Thickness (cm) .................................... 32 


\section{Introduction}

\subsection{Purpose}

1.1.1 To encourage energy efficient design or retrofit of commercial buildings so that they may be constructed, operated, and maintained in a manner that reduces the use of energy without constraining the building function, the comfort, health, or the productivity of the occupants and with appropriate regard for economic considerations.

1.1.2 To provide criterion and minimum standards for energy efficiency in the design or retrofit of commercial buildings and provide methods for determining compliance with them.

1.1.3 To encourage energy efficient designs that exceed these criterion and minimum standards.

\subsection{Scope}

1.2.1 This energy efficiency building code (EEBC) sets forth the requirements for design or retrofit of commercial buildings used primarily for human occupancy.

1.2.2 The requirements pertain to commercial buildings such as offices, hotels, shopping complexes, hospitals, and others that are not primarily for residential or industrial use.

1.2.3 This EEBC covers the following building elements: exterior envelopes, systems for ventilation and air-conditioning, electric power and distribution, lighting, and service water heating.

1.2.4 All commercial buildings meeting ANY of the following criteria must meet the requirements of this EEBC:

(a) Four stories or higher

(b) Floor area of $2,000 \mathrm{~m}^{2}$ or greater

(c) Building enclosed volume of $5,600 \mathrm{~m}^{3}$ or greater

(d) Electrical peak demand of $125 \mathrm{kVA}$ or greater

(e) Air-conditioning cooling capacity of $350 \mathrm{~kW}$ (output)

1.2.5 Residential and industrial buildings are exempted.

1.2.6 This EEBC covers only the energy performance aspects of the building and not other aspects such as health and safety. This in no way replaces other requirements of building design, construction, or occupancy that may apply. All other codes and regulations pertaining to buildings are still in effect.

1.2.7 This EEBC assumes professional expertise in building design and construction for the covered areas and systems. It is not intended as a design manual on energy efficient design practice. 


\section{Lighting}

\subsection{General Principles of Energy Efficient Lighting Practice.}

Lighting is one of the single largest consumers of energy (kilowatt-hours) in a building. A number of lighting technologies are available that can significantly reduce the amount of energy needed for lighting. In addition to consuming energy, the lighting load can also have an impact on the cooling load as lighting generates heat. The effect of added lighting load on a building's cooling requirements is particularly significant for warm climates.

This code will limit the maximum allowable lighting load for the building lighting system as well as place lower limits on the acceptable efficiencies of commonly used lighting components (lamps and ballasts). An energy efficient light system can provide a flexible, effective, and pleasing visual environment for a space and, at the same time, minimize energy consumption.

\subsection{Scope}

2.2.1 Spaces Covered. The rooms, spaces and areas covered by this section include:

(a) Interior spaces of buildings

(b) Building exterior areas including facade lighting, entrances, exits, loading docks, etc.

(c) Roads, grounds and other exterior areas including open-air covered areas where lighting is installed and is powered by the building electrical service.

2.2.2 Spaces Exempted. The following rooms, spaces, areas and equipment exempted from this section include:

(a) Commercial greenhouses

(b) Lighting power for theatrical productions, television broadcasting, those portions of entertainment facilities such as stage areas in hotel ballrooms, night-clubs, discos and casinos where lighting is an essential technical element of the function performed.

(c) Specialized luminaires for medical and dental purposes.

(d) Outdoor athletic facilities

(e) Exterior lighting of public monuments

(f) Special lighting needs of research laboratories.

(g) Lighting used solely for indoor plant growth during the hours of 10:00 PM and 6:00 am

(h) Emergency lighting that is automatically OFF during normal operation

(i) High-risk security areas identified by local ordinances or regulation or by security or safety personnel requiring additional lighting.

2.2.3 Light Source Selection. The use of incandescent or tungsten halogen lamps for general lighting should be discouraged. General lighting should ordinarily be provided with fluorescent lamps. Although incandescent and tungsten halogen light sources are often the least expensive to install, they are energy inefficient and are usually less cost effective than efficient sources such as fluorescent lighting. Incandescent lamps use more energy to supply a given light level than fluorescent or high intensity discharge 
(HID) sources. Furthermore, they must be replaced much more frequently. Consequently, the life cycle cost of fluorescent and HID sources is usually lower than that of incandescent lamps even though the initial installed costs may be higher. This is especially true of commercial buildings which typically have long lighting operation hours (compared to residences).

Use compact fluorescent lamps in "downlights" in ceilings under 4 meters. For "high bay" applications (ceilings over 4 meters), use high pressure sodium or metal halide lamps.

2.2.4 General and Task Lighting Considerations. It is energy wasteful to provide the maximum required light level everywhere throughout a facility. The middle illuminance level, for a given task, in Table 2-1 below will provide adequate lighting for most of the people and tasks. Where a person or task requires a higher light level, task lighting should be provided. Fluorescent lighting is an ideal and efficacious source for general lighting in commercial buildings. Task lighting can be provided by CFL, halogen, and incandescent sources. Table 2-1 provides recommendations for the illuminance levels in different portions of a building.

\subsection{Recommended Illuminance Levels.}

2.3.1 Lighting needs in most buildings vary according to specific space type. For example, low light levels are acceptable for corridors while higher light levels should be used for desk locations. The following table is a list of recommended illuminance levels for different building and space types. This table should be used as guidance for designing lighting systems in commercial buildings. 
Table 2-1. Recommended Illuminance Levels and Glare Indices

\begin{tabular}{|c|c|c|c|c|}
\hline & \multicolumn{3}{|c|}{ Illuminance (Lux) $^{\mathrm{a}}$} & \multirow{2}{*}{$\begin{array}{c}\text { Limiting } \\
\text { Glare Index } \\
\end{array}$} \\
\hline & Recommended & Low & High & \\
\hline \multicolumn{5}{|l|}{ HOTELS } \\
\hline Bathrooms & 150 & 100 & 200 & \\
\hline Bed Rooms, General & 75 & 50 & 100 & \\
\hline Bed Rooms, Reading & 300 & 200 & 500 & \\
\hline Corridors, elevators and stairs & 150 & 100 & 200 & \\
\hline Front Desk & 500 & 300 & 750 & \\
\hline Lobby, Reading and working area & 300 & 200 & 500 & \\
\hline Lobby, General Lighting & 150 & 100 & 200 & \\
\hline \multicolumn{5}{|l|}{ OFFICES } \\
\hline Accounting & 300 & 200 & 500 & 19 \\
\hline Audio Visual areas & 300 & 200 & 500 & 19 \\
\hline Conference areas & 300 & 200 & 500 & 16 \\
\hline General and private offices & 300 & 200 & 500 & 19 \\
\hline Libraries & 300 & 200 & 500 & 19 \\
\hline Lobbies, lounges and reception areas & 150 & 100 & 200 & 19 \\
\hline Off-set printing and duplicating area & 300 & 200 & 500 & 19 \\
\hline \multicolumn{5}{|l|}{ HOSPITALS } \\
\hline Consulting areas, General & 300 & 200 & 500 & \\
\hline Consulting areas, Examination & 500 & 300 & 750 & \\
\hline Corridors, General & 150 & 100 & 200 & \\
\hline Ward Corridors, Day & 200 & 150 & 300 & \\
\hline Ward Corridors, Night & & 5 & 10 & \\
\hline Laboratories, General & 300 & 200 & 500 & \\
\hline Laboratories, Examination & 500 & 300 & 750 & \\
\hline Nurses Stations & 300 & 200 & 500 & \\
\hline Ward Bed Head & & 30 & 50 & \\
\hline Ward Bed Head, Reading & 150 & 100 & 200 & \\
\hline Surgeries, General & 300 & 200 & 500 & \\
\hline Surgeries, Waiting rooms & 150 & 100 & 200 & \\
\hline \multicolumn{5}{|l|}{ BANKS } \\
\hline Lobby, General & 150 & 100 & 200 & 19 \\
\hline Lobby, Writing area & 300 & 200 & 500 & 19 \\
\hline Tellers' stations & 500 & 300 & 750 & 19 \\
\hline \multicolumn{5}{|l|}{ SHOPS \& STORES } \\
\hline Conventional with counters & 300 & 200 & 500 & 19 \\
\hline Conventional with wall display & 300 & 200 & 500 & 19 \\
\hline Self Service & 300 & 200 & 500 & 19 \\
\hline Supermarkets & 500 & 300 & 750 & 22 \\
\hline
\end{tabular}

a The recommended value is for "average" age workers (age 30-70) performing important tasks. The low value is appropriate for younger workers performing non-critical tasks. The high value should be used for older workers or workers more than 30 years old performing critical tasks.

${ }^{\mathrm{b}}$ See Chartered Institution for Building Services Engineers (CIBSE) Code for Interior Lighting, London, Great Britain, 1994. for definition of glare index. 


\subsection{Lighting Equipment Efficiency Levels}

2.4.1 Fluorescent. Use the most efficient lamp that is cost-effective for the application. Table of fluorescent lamps minimum efficacies (lumens/W). The lamp efficacy shall not be below the values indicated in Table 2-2 for linear fluorescent lamps and in Table 2-3 for compact fluorescent lamps. Note that the lamp efficacy is the efficacy of the lamp alone. It does not include the ballast losses. It is found by dividing the lamp's rated light output (in lumens) by the rated lamp power (watts). For the system LPD limits (which include both lamp and ballast) see section 2.5 .

Table 2-2. Minimum Lamp Efficacy Linear Fluorescent Lamps (0.6 to 1.2 meters)

\begin{tabular}{|c|c|c|c|}
\hline $\begin{array}{l}\text { Lamp } \\
\text { Length } \\
\text { (mm) }\end{array}$ & $\begin{array}{l}\text { Lamp } \\
\text { Power } \\
\text { (watts) }\end{array}$ & $\begin{array}{l}\text { Diameter } \\
\text { (mm) }\end{array}$ & $\begin{array}{l}\text { Minimum Lamp } \\
\text { Efficacy } \\
\text { (lumens/Watt) }\end{array}$ \\
\hline 600 & 18 & 26 & 55 \\
\hline 1200 & 36 & 26 & 66 \\
\hline 1500 & 58 & 26 & 66 \\
\hline
\end{tabular}

Table 2-3. Minimum Lamp Efficacy Integral-Type Compact Fluorescent Lamps

\begin{tabular}{|c|c|}
\hline $\begin{array}{l}\text { Lamp } \\
\text { Power } \\
\text { (watts) }\end{array}$ & $\begin{array}{l}\text { Minimum } \\
\text { Lamp Efficacy } \\
\text { (lumens/Watt) }\end{array}$ \\
\hline 9 & 42 \\
\hline 11 & 52 \\
\hline 15 & 57 \\
\hline 20 & 57 \\
\hline 23 & 62 \\
\hline
\end{tabular}

Table 2-4. Minimum Lamp Efficacy Modular-Type Compact Fluorescent Lamps

\begin{tabular}{|c|c|c|}
\hline $\begin{array}{c}\text { Lamp } \\
\text { Power } \\
\text { (Watts) }\end{array}$ & $\begin{array}{c}\text { Minimum } \\
\text { Lamp Efficacy } \\
\text { (lumens/Watt) }\end{array}$ & $\begin{array}{c}\text { Ballast } \\
\text { Loss } \\
\text { (Watts) }\end{array}$ \\
\hline 7 & 54 & 6 \\
\hline 10 & 57 & 6 \\
\hline 11 & 78 & 5 \\
\hline 13 & 66 & 5 \\
\hline 18 & 63 & 7 \\
\hline
\end{tabular}

2.4.1.1 Fluorescent ballast loss maxima. For linear fluorescent lamp ballasts, the ballast losses shall not exceed the values given in Table 2-5. 
Table 2-5. Maximum Allowed Ballast Loss for Linear Fluorescent Lamps

\begin{tabular}{|c|c|}
\hline Ballast Type & $\begin{array}{c}\text { Maximum Allowed } \\
\text { Ballast Loss } \\
\text { (W) }\end{array}$ \\
\hline Electromagnetic & 8 \\
For 18 W single-lamp & 8 \\
For 36 W single-lamp & 4 \\
\hline Electronic & 6 \\
For 18 W single-lamp & 4 \\
For 18 W two-lamp & 7 \\
For 36 W single-lamp & \\
For 36 W two-lamp & \\
\hline
\end{tabular}

2.4.2 Incandescent. The lamp efficacy for incandescent lamps should not be below the efficacies listed in Table 2-6.

Table 2-6. Incandescent Lamp- Minimum Lamp Efficacy

\begin{tabular}{|c|c|}
\hline $\begin{array}{c}\text { Lamp } \\
\text { Power } \\
\text { (watts) }\end{array}$ & $\begin{array}{l}\text { Minimum Lamp } \\
\text { Efficacy } \\
\text { (lumens/Watt) }\end{array}$ \\
\hline 40 & 10.6 \\
\hline 60 & 12.0 \\
\hline 75 & 12.7 \\
\hline 100 & 13.6 \\
\hline
\end{tabular}

2.4.3 High Intensity Discharge. The lamp efficacy for High Intensity Discharge lamps (e.g. sodium, metal halide, mercury) should not be below the efficacies listed in Table 27, and the ballast losses for HID lamps should not exceed the values in Table 2-7.

Table 2-7. HID Lamp - Minimum Lamp Efficacy \& Maximum Allowed Ballast Loss

\begin{tabular}{|c|c|c|}
\hline $\begin{array}{c}\text { Lamp } \\
\text { Power } \\
\text { (Watts) }\end{array}$ & $\begin{array}{l}\text { Minimum } \\
\text { Lamp Efficacy } \\
\text { (lumens/Watt) }\end{array}$ & $\begin{array}{c}\text { Maximum } \\
\text { Allowed } \\
\text { Ballast Loss } \\
\text { (Watts) }\end{array}$ \\
\hline 50 & 57 & 10 \\
\hline 70 & 64 & 15 \\
\hline 100 & 53 & 15 \\
\hline 150 & 76 & 20 \\
\hline 175 & 70 & 22 \\
\hline 250 & 74 & 26 \\
\hline 320 & 67 & 28 \\
\hline 400 & 68 & 30 \\
\hline 1000 & 104 & 60 \\
\hline 1500 & 98 & 85 \\
\hline
\end{tabular}


2.4.4 Fluorescent Luminaires. Where fixture manufacturer information is available, use the most efficient fixtures appropriate to the application. The efficiency of a lighting fixture is given by its Light Output Ratio (L.O.R.) which is defined as the ratio of the lumens from the luminaire divided by the sum of the individual lumen values of the lamps inside the luminaire. For most fixtures used in commercial buildings, this information is available from the fixture manufacturer.

For general-purpose fluorescent lighting systems, use fixtures that have an L.O.R. of at least 0.50 . Exceptions to this would be a space with critical glare control needs (highend graphics workstation, for example).

2.4.5 Emergency and Exit Lighting. Exit sign luminaires operating at greater than 20 Watts shall have a minimum source efficacy of 35 lumens per Watt. Where possible, LEDs should be used in exit signs.

Emergency lighting includes all of egress lighting, illuminated exit signs, and all other lights specified as necessary to provide the required illumination. Emergency lights systems shall be so designed and installed that failure of any individual lighting element, such as the burning out of a light bulb, cannot leave any space that requires emergency illumination in total darkness. Switches installed in emergency lighting circuits shall be so arranged that only authorized persons will have control of emergency lighting.

2.5 Maximum Allowable Power for Illumination Systems. The lighting power density (LPD) for building lighting systems shall not exceed the values given in Table 2-8. LPD is calculated by dividing the total connected load for all lighting systems in the building by the gross lighted floor area of the building. For building types not listed in Table 2-8, selection of a reasonable equivalent is permitted.

Table 2-8. Maximum Allowed Lighting Power Density

\begin{tabular}{|l|c|}
\hline Building Type & $\begin{array}{l}\text { Maximum } \\
\text { Allowed } \\
\text { Lighting } \\
\text { Power Limits } \\
\text { (Watts/m }\end{array}$ \\
\hline General Commercial Building & 13 \\
\hline Commercial Storage Building & 9 \\
\hline Medical Buildings and Clinics & 16 \\
\hline Office Building & 16 \\
\hline Hotels/Motels & \\
Guest rooms and corridors & 17 \\
Public, banquet, and exhibit areas & 20 \\
\hline Food Service & 16 \\
\hline Shops & 22 \\
\hline Schools & 19 \\
\hline All Others & 9 \\
\hline
\end{tabular}




\subsection{Building Exterior Lighting Power}

2.6.1 Building exterior and grounds lighting power densities. The connected lighting power shall not exceed the power limits specified in Tables 2-9 and 2-10 for each of the listed building exterior applications. Trade-offs between applications are not permitted.

Table 2-9. Maximum Allowed Lighting Power for Building Exteriors

\begin{tabular}{|l|l|}
\hline Application & $\begin{array}{l}\text { Maximum Allowed Power } \\
\text { Limits (W/linear m) }\end{array}$ \\
\hline $\begin{array}{l}\text { Building entrance (with canopy) } \\
\text { Low Traffic (hospital, office, school) }\end{array}$ & 32.4 (of canopied area) \\
High Traffic (retail, hotel, airport, theater) & 64.8 (of canopied area) \\
\hline Building entrance (without canopy) & 98.4 (of door width) \\
\hline Building Exit & 65.6 (of door width) \\
\hline Loading & \\
Loading Area & $3.0\left(\mathrm{~W} / \mathrm{m}^{2}\right)$ \\
Loading Door & 50.0 (of door width) \\
\hline
\end{tabular}

Table 2-10. Maximum Allowed Lighting Power for Roads/Grounds

\begin{tabular}{|l|c|}
\hline Application & $\begin{array}{l}\text { Maximum Allowed } \\
\text { Power Limits (W/m }{ }^{2} \text { ) }\end{array}$ \\
\hline Storage and work area & 2.0 \\
\hline $\begin{array}{l}\text { Areas for casual use (picnic grounds, } \\
\text { gardens, parks, landscaped areas) }\end{array}$ & 1.0 \\
\hline $\begin{array}{l}\text { Driveways,/walkways } \\
\quad \text { Private }\end{array}$ & 1.0 \\
$\quad$ Public & 1.5 \\
\hline Parking Lots & 1.2 \\
$\quad$ Private & 1.8 \\
Public & \\
\hline
\end{tabular}

\subsection{Lighting Controls}

2.7.1 Area Controls. The simplest way to improve lighting efficiency is to turn off lights when they are not in use. All lighting systems must have switching or control capabilities to allow lights to be turned off when they are not needed.

(a) All spaces enclosed by walls or ceiling height partitions shall be provided with one manually operated on/off lighting control (switch) for each space. Each space must have its own switching; gang switching of several spaces is not permitted.

(b) The total number of switches shall not be less than one switch per 1000 Watts controlled load. 
(c) All manually operated switching devices must be located so that personnel can see the controlled area when operating the switch(es). In public areas, such as lobbies, concourses, etc., the switches may be located in areas accessible to authorized personnel only.

2.7.2 Exceptions. Continuously illuminated areas within a building, for reasons of security or emergency egress, are exempt from the switching requirements as long as the maximum lighting power density used for this purpose does not exceed 0.05 watts per square meter.

2.7.3 Exterior Lighting. Exterior lighting shall be automatically controlled by a photosensor or timer.

2.7.4 Daylighted Area Control. Electric lighting in enclosed areas greater than 23 square meters that are "daylit areas" ", must be switched so that the lighting in these areas can be controlled separately from the non-daylit areas. It is acceptable to achieve control of the daylit area by shutting off at least $50 \%$ of the lamps within the daylit area. This must be done by a control dedicated to serving only luminaires in the daylit area.

Separate control of daylit areas is not required when there is not enough daylight to be used effectively (e.g., if a window is so obstructed by adjacent structures, trees, or other natural objects that the effective use of daylighting is not feasible).

2.7.5 Lighting Controls Credits. To encourage the use of lighting controls beyond the mandatory switching requirements of Section 2.6.1, the connected lighting power within a building may be adjusted to take credit for the benefits of certain types of automatic lighting controls. The lighting control credit is a multiplier that reduces the amount of energy used for lighting, giving a lower adjusted lighting power. In order to qualify for a lighting power density reduction, the control device must control all of the fixtures for which the credit is claimed. At least $50 \%$ of the light output of the controlled luminaire must fall within the applicable type of space listed in Table 2-9. The list of the type of lighting controls that qualify for these credits is shown in Table 2-9.

\footnotetext{
1 "Daylit Area" is the space on the floor that is daylit by vertical glazing. The daylit area has a length of 1.5 meters, or the distance on the floor, perpendicular to the glazing, to the nearest 0.5 meters or higher opaque partition, whichever is less; and the width of the window plus 0.2 meters on each side or the distance to an opaque partition, whichever is least.
} 
Table 2-11. Power Credits for Certain Types of Lighting Controls

\begin{tabular}{|c|l|c|}
\hline Type of Control & Type of Space & Factor \\
\hline \multirow{2}{*}{$\begin{array}{c}\text { Occupant Sensor (with separate } \\
\text { sensor for each space) }\end{array}$} & $\begin{array}{l}\text { Any space }<\text { or }=23 \mathrm{~m}^{2} \text { enclosed by ceiling } \\
\text { to floor partitions: any size classroom, } \\
\text { corridor, conference or waiting room }\end{array}$ & 0.20 \\
\cline { 2 - 3 } & $\begin{array}{l}\text { Rooms of any size that are used exclusively } \\
\text { for storage }\end{array}$ & 0.60 \\
\cline { 2 - 3 } & Rooms $>23 \mathrm{~m}^{2}$ & 0.10 \\
\hline \multirow{2}{*}{$\begin{array}{c}\text { Automatic Time Switch Control } \\
\text { Device }\end{array}$} & $\begin{array}{l}\text { Room < or }=23 \mathrm{~m}^{2} \text { and with a timed manual } \\
\text { override at each switch location and } \\
\text { controlling only the lights in the area } \\
\text { enclosed by ceiling-height partitions }\end{array}$ & 0.05 \\
\hline
\end{tabular}

Table 2-12. Power Credits for Automatic Daylighting Controls

\begin{tabular}{|l|c|c|c|c|c|c|}
\hline \multirow{3}{*}{ Glazing Properties } & \multicolumn{3}{|c|}{ Stepped Dimming Controls } & \multicolumn{3}{c|}{ Continuous Dimming Controls } \\
\cline { 2 - 7 } & $\begin{array}{c}\text { WWR } \\
<20 \%\end{array}$ & $\begin{array}{c}\text { WWR } \\
20 \% \text { to } 40 \%\end{array}$ & $\begin{array}{c}\text { WWR } \\
>40 \%\end{array}$ & $\begin{array}{c}\text { WWR } \\
<20 \%\end{array}$ & $\begin{array}{c}\text { WWR } \\
20 \% \text { to } 40 \%\end{array}$ & $\begin{array}{c}\text { WWR } \\
>40 \%\end{array}$ \\
\hline $\mathrm{VLT} \geq 60 \%$ & 0.20 & 0.30 & 0.40 & 0.30 & 0.40 & 0.40 \\
\hline $\mathrm{VLT} \geq 35$ and $<60 \%$ & 0 & 0.20 & 0.30 & 0 & 0.30 & 0.40 \\
\hline $\mathrm{VLT}<35 \%$ & 0 & 0 & 0.20 & 0 & 0 & 0.40 \\
\hline
\end{tabular}

The lighting control credits listed in Tables 2-11 and 2-12 have the effect of reducing the actual lighting power for those portions of the building where the credit applies by the amount listed in the tables. The credits therefore make it easier to meet the allowed lighting power requirement.

In order to qualify for power savings adjustment, the control system or device must control all of the fixtures in the areas for which the credit is claimed. At least $50 \%$ of the light output of the controlled luminaire must fall within the applicable space listed in the table. Credits may not be combined.

2.7.6 Hotel and motel guest rooms shall have a master switch at the door that turns off all permanently wired lighting fixtures except for security lighting, if required.

\subsection{Submission Procedure}

2.8.1 The Engineer or Architect responsible for the lighting installation shall provide a complete set of plans to the Building Owner showing the installed lighting devices and including the following information.

(a) The design standard service illuminance.

(b) The number of each type of lighting device

(c) The total wattage of each type of lighting device, including nominal rating and control losses.

(d) The installed lighting load for interior and exterior. 


\section{Ventilation and Air Conditioning}

\subsection{Load Calculations}

3.1.1 Calculation Procedures. Cooling system design loads for the purpose of sizing systems and equipment shall be determined in accordance with the procedures described in the latest edition of the ASHRAE Handbook or other equivalent publications.

3.1.2 Indoor Design Conditions. The indoor conditions of an air-conditioned space shall be designed for a dry bulb temperature of $24^{\circ} \mathrm{C} \pm 1{ }^{\circ} \mathrm{C}$ and relative humidity of $55 \%$ $\pm 5 \%$. Further energy savings could be achieved by raising the dry bulb temperature limit during operation without compromising occupant comfort.

3.1.3 Outdoor Design Conditions. Dry bulb temperature of $32^{\circ} \mathrm{C}$ and wet bulb temperature of $27^{\circ} \mathrm{C}$.

3.1.4 Ventilation and exhaust. Outdoor air ventilation rates shall comply with ASHRAE Standard 62, 1999 (ANSI/ASHRAE 62-1999, Ventilation for Acceptable Indoor Air Quality). Outdoor air quantities may exceed those shown in Standard 62 if required because of special occupancy or process requirements or source control of air contamination.

\subsection{System and Equipment Sizing}

3.2.1 AC systems and equipment shall be sized to provide no more than the space and system loads calculated in accordance with sub-section 3.1 above, consistent with available equipment capacity.

3.2.2 Where chillers are used and when the design load is greater than $700 \mathrm{~kW}$, the equipment shall have a minimum of two separate refrigerant circuits to meet the required load.

3.2.3 Multiple units of the same equipment type, such as multiple chillers, with combined capacities exceeding the design load may be specified to operate concurrently only if controls are provided that sequence or otherwise optimally control the operation of each unit based on load.

3.2.4 Capacity of any individual unit shall not be less than 20kW (output), excepting backup units for specified areas.

\subsection{Fan System Design Criteria}

3.3.1 General. The following design criteria apply to all AC fan systems used for comfort ventilating and/or air conditioning. For the purposes of this sub-section, the energy demand of a fan system is the sum of the demand of all fans that are required to operate at design conditions to supply air from the cooling source to the conditioned space(s) and return it back to the source or exhaust it to the outdoors. 
3.3.2 EXCEPTIONS. Systems with total fan system nameplate motor power of $4 \mathrm{~kW}$ or less.

3.3.3 Constant Volume Fan Systems. For fan systems that provide a constant air volume whenever the fans are operating, there shall be at least $590 \mathrm{~L} / \mathrm{s}$ of supply air volume per $\mathrm{kW}$ of total input power required by the motors for the combined fan system at design conditions.

3.3.4 Variable Air Volume (VAV) Fan Systems. For fan systems that are able to vary system air volume automatically as a function of load, there shall be at least $420 \mathrm{~L} / \mathrm{s}$ of supply air volume per $\mathrm{kW}$ of total input power required by the motors for the combined fan system at design conditions.

\subsection{Pumping System Design Criteria}

3.4.1 General. The following design criteria apply to all pumping systems used for comfort air conditioning. For the purposes of this sub-section, the energy demand of a pumping system is the sum of the demand of all pumps that are required to operate at design conditions to supply fluid from the cooling source to the conditioned space(s) or heat transfer device(s) and return it back to the source.

3.4.2 Friction Rate. Piping systems shall be designed at friction pressure loss rate of no more than 2 metre of water per 100 equivalent metre of pipe, subject to the velocity in the system pipe lines not exceeding $2.5 \mathrm{~m} / \mathrm{s}$. Lower friction rates may be required for proper noise or corrosion control.

3.4.3 Sizing, Selection, and System Design. The following aspects of pumping systems should be designed to minimize life-cycle system costs. Pipe size, components, and layout should be optimized to reduce system pressure drops, thus reducing the pump and motor sizes required. Once the operating flow and pressure are established, the pump should be carefully selected for maximum efficiency, and not less than $70 \%$. The flow rate should never exceed $110 \%$ of design flow. Once the pump shaft power requirement is determined, the motor with the highest efficiency at the design load should be selected that meets or exceeds the values in Table 5-3 Minimum Motor Efficiencies. The motor horsepower rating should not exceed $125 \%$ of the calculated maximum load being served. If a standard rated motor is not available within the range, the next largest standard motor size may be used. It is recommended that pump speeds be less than $1500 \mathrm{rpm}$. Variable-speed pumps should be considered for variable-flow systems, especially for large systems. Variable-flow chilled water systems should also be evaluated (either variable flow through the chiller, as allowed by many manufacturers; or primary-secondary pumping systems with constant chiller flow and variable building system flow).

3.4.4 Variable Flow. Pumping systems that serve control valves designed to modulate or step open and closed as a function of load, shall be designed for variable fluid flow. Flow may be varied using variable-speed driven pumps, staged multiple pumps, or pumps riding their characteristic curves. 


\subsubsection{EXCEPTIONS:}

(a) Systems where a minimum flow greater than $50 \%$ of the design flow is required for the proper operation of equipment served by the system, such as some chillers.

(b) Systems that serve no more than one control valve.

\subsection{Separate Air Distribution Systems}

3.5.1 Zones with Non-Simultaneous Operation. Zones that are expected to operate non-simultaneously for more than 300 hours per year shall be served by separate air distribution systems. As an alternative, off-hour controls shall be provided in accordance with Section 3.7.3.

3.5.2 Zones with Special Process Requirements. Zones with special process temperature and/or humidity requirements shall be served by separate air distribution systems from those serving zones requiring only comfort cooling, or shall include supplementary provisions so that the primary systems may be specifically controlled for comfort purposes only.

3.5.3 EXCEPTIONS. Zones requiring comfort cooling only, which are served by a system primarily used for process temperature and humidity control, need not be served by a separate system if the total supply air to these zones is no more than $25 \%$ of the total system supply air, or the total conditioned floor area of the zones is less than 100 $\mathrm{m}^{2}$.

3.5.4 Zones with Different Load Characteristics. Separate air distribution systems should be considered for areas of the building having substantially different cooling characteristics, such as perimeter zones in contrast to interior zones.

\subsection{Temperature Controls}

3.6.1 System Control. Each AC system shall include at least one temperature control.

3.6.2 Zone Controls. The supply of cooling energy to each zone shall be controlled by individual thermostatic controls responding to temperature within the zone.

3.6.3 Thermostats. Zone controls should be set no lower than indoor design conditions $\left(24^{\circ} \mathrm{C}\right)$. Temperature sensors shall be located in the zone or the return air path.

\subsection{Off-Hour Controls}

3.7.1 Equipment Shutdown During Non-Use. AC systems shall be equipped with automatic controls capable of accomplishing a reduction of energy use through equipment shutdown, or increase in the temperature set point, during periods of non-use or alternative use of the spaces served by the system. 


\subsubsection{EXCEPTIONS:}

(a) Systems serving areas that are expected to operate continuously.

(b) Equipment with a connected load of $2 \mathrm{~kW}$ or less may be controlled by readily accessible manual off-hour controls.

3.7.3 Outside Air Control During Non-Use. Outdoor air supply and exhaust systems shall be provided with motorized or gravity dampers or other means of automatic volume shutoff or reduction during periods of non-use of alternative use of the spaces served by the system.

\subsubsection{EXCEPTIONS:}

(a) Systems serving areas that are expected to operate continuously.

(b) Systems that have a design air flow of $500 \mathrm{~L} / \mathrm{s}$ or less.

(c) Gravity and other non-electrical ventilation systems may be controlled by readily accessible manual damper controls.

(d) Where restricted by process requirements such as combustion-air intakes.

3.7.5 Zones with Non-Simultaneous Operation. Systems that serve zones that can be expected to operate non-simultaneously for more than 300 hours per year shall include isolation devices and controls to shut off the supply of cooling to each zone independently. For central systems and plants, controls and devices shall be provided to allow stable system and equipment operation for any length of time while serving only the smallest isolation area served by the system or plant. Isolation is not required for zones expected to operate continuously. For buildings where occupancy patterns are not known at the time of the system design, such as speculative buildings, isolation areas may be predesigned. Zones may be grouped into a single isolation area provided the total conditioned floor area does not exceed $250 \mathrm{~m}^{2}$ per group nor include more than one floor.

\subsection{Piping Insulation}

3.8.1 Chilled Water Piping. All AC system chilled water piping shall be thermally insulated in accordance with Table 3-1 not only to reduce heat gain from the outside, but also to avoid condensation on the surface of the installation. The insulation shall be suitably protected from damage. Reference is to be made to the insulation manufacturer's catalogue.

3.8.2 EXCEPTIONS. Piping insulation shall not be required in any of the following areas:

(a) Piping that conveys fluids that have a design temperature above $20^{\circ} \mathrm{C}$. Note that if the indoor design conditions are exceeded, insulation may be required on higher temperature piping to prevent condensation.

(b) Piping that conveys fluids that have not been heated or cooled through the use of fossil fuels or electricity. 
Table 3-1. Piping Insulation

\begin{tabular}{|c|c|c|c|c|c|}
\hline \multirow{2}{*}{$\begin{array}{l}\text { Piping } \\
\text { System } \\
\text { Type }\end{array}$} & \multirow{2}{*}{$\begin{array}{l}\text { Fluid } \\
\text { Temp } \\
\text { Range } \\
\left({ }^{\circ} \mathrm{C}\right)\end{array}$} & \multicolumn{4}{|c|}{$\begin{array}{l}\text { Insulation Thickness for Nominal Pipe Sizes } \\
\qquad(\mathrm{mm})\end{array}$} \\
\hline & & $\begin{array}{l}\text { Runouts } \\
\text { Up to } 50 \\
\mathrm{~mm}\end{array}$ & $\begin{array}{l}25 \mathrm{~mm} \\
\text { and less }\end{array}$ & $\begin{array}{l}32 \mathrm{~mm} \text { to } \\
50 \mathrm{~mm}\end{array}$ & $\begin{array}{l}63 \mathrm{~mm} \\
\& \text { above }\end{array}$ \\
\hline $\begin{array}{l}\text { Chilled } \\
\text { Water }\end{array}$ & $4.5-13$ & 13 & 13 & 25 & 38 \\
\hline $\begin{array}{l}\text { Refrigerant or } \\
\text { Brine }\end{array}$ & $\begin{array}{l}\text { Below } \\
4.5\end{array}$ & 25 & 25 & 38 & 50 \\
\hline \multicolumn{6}{|c|}{$\begin{array}{l}\text { Notes: } 1 \text {. The insulation thickness is based on insulation having thermal } \\
\text { resistance in the range of } 28 \text { to } 32 \mathrm{~m}^{2} \mathrm{~K} / \mathrm{W} \text { per metre of thickness on a flat } \\
\text { surface at a mean temperature of } 24^{\circ} \mathrm{C} \text {. See } 4.8 .2 \text { and } 4.8 .3 \text { for insulation } \\
\text { materials with thermal resistance outside this range. } \\
\text { 2. These thicknesses are based on energy efficiency considerations only. } \\
\text { Issues such as water vapor permeability or surface condensation may } \\
\text { require vapor retarders or additional insulation. }\end{array}$} \\
\hline
\end{tabular}

3.8.3 Chilled Water Piping. For material with thermal resistance greater than $32 \mathrm{~m}^{2}$ $\mathrm{K} / \mathrm{W}$ per metre of thickness, the minimum insulation thickness, $\mathrm{t}(\mathrm{mm})$, is given by:

$28 \times$ Thickness in Table 3-1

$\mathrm{t}=$ Actual $\mathrm{R}$ Value

3.8.4 Chilled Water Piping. For material with thermal resistance less than $28 \mathrm{~m}^{2} \mathrm{~K} / \mathrm{W}$ per metre of thickness, the minimum insulation thickness, $t(\mathrm{~mm})$, is given by:

$32 \times$ Thickness in Table 3-1

$\mathrm{t}=$

Actual R Value

\subsection{Air Handling System Insulation}

3.9.1 AC System Ducts and Plenums. All air-handling ducts and plenums installed as part of an $A C$ air distribution system shall be thermally insulated.

3.9.2 EXCEPTIONS. Duct insulation is not required in any of the following cases:

(a) Factory installed plenums, casings, or ductwork furnished as a part of AC equipment, provided that they are either insulated at the factory or installed in a conditioned space.

(b) Exhaust air ducts.

(c) Outdoor air ducts.

(d) Return air ducts within conditioned space. 
3.9.3 Thermal Resistance Requirement. The minimum thermal resistance, $R\left(m^{2} K / W\right)$, of the insulation, excluding film resistance shall be:

$$
R=\frac{\Delta T}{47.3}
$$

where $\Delta T=$ design temperature differential between the air in the duct and the surrounding air in $\mathrm{K}$

\subsection{Air Handling System Ducts.}

3.10.1 Ductwork and plenums shall be sealed in accordance with Table 3-2 and with standard industry practice as defined in SMACNA 1995 (Sheet Metal and Air Conditioning Contractors' National Association, HVAC Duct Construction Standards Metal \& Flexible, 1995). 
Table 3-2. Minimum Duct Seal Level

\begin{tabular}{|c|c|c|c|c|}
\hline \multirow{3}{*}{ Duct Location } & \multicolumn{4}{|c|}{ Duct Type } \\
\hline & \multicolumn{2}{|c|}{ Supply } & \multirow{2}{*}{ Exhaust } & \multirow[t]{2}{*}{ Return } \\
\hline & $<500 \mathrm{~Pa}^{\mathrm{a}}$ & $\geq 500 \mathrm{~Pa}^{\mathrm{a}}$ & & \\
\hline Outside Conditioned Space & 1 & 1 & none & 1 \\
\hline Unconditioned Spaces & 2 & 1 & none & 3 \\
\hline $\begin{array}{c}\text { Indirectly Conditioned } \\
\text { Spaces }^{\mathrm{b}}\end{array}$ & 3 & 2 & 3 & none \\
\hline Cooled Spaces & None & $3^{c}$ & $3^{c}$ & none \\
\hline
\end{tabular}

${ }^{a}$ Duct design static pressure classification. Unless otherwise shown in design documents, ductwork between the supply fan and variable air volume boxes shall be considered $500 \mathrm{~Pa}$ pressure classification, while all other ductwork of any application shall be considered $250 \mathrm{~Pa}$ pressure classification.

b Includes return-air plenums.

${ }^{c}$ Ducts within the conditioned space to which they supply air or from which they exhaust air need not be sealed.

Seal Levels:

1. All joints, longitudinal seams, and at all duct wall penetrations. Pressure-sensitive tape shall not be used as the primary sealant.

2. All joints and longitudinal seams. Pressure-sensitive tape shall not be used as the primary sealant.

3. Transverse joints only.

Definitions: Longitudinal seams are joints oriented in the direction of airflow. Transverse joints are connections of two duct sections oriented perpendicular to airflow. Duct wall penetrations are openings made by any screw or fastener. Spiral lock joints in round and flat-oval duct need not be sealed. All other connections are considered joints, including but not limited to spin-ins, lateral taps and other branch connections, access door frames and jambs, duct connections to equipment, etc.

\subsection{AC Equipment}

3.11.1 Minimum Equipment Performance. Equipment shall meet or exceed the minimum performance shown in Table 3-4 when tested at the standard rating conditions shown in Table 3-3. Note that except for the cooling towers, the rating conditions are those used internationally (for ease of comparison) rather than being typical of Sri Lanka conditions. VAC designers should determine equipment load profiles and obtain applied part-load values (APLVs) from the manufacturers to better estimate the actual energy use of the equipment as it will be used. With the load and APLV information, designers should then select equipment based on minimizing life-cycle cost of the system. 
Table 3-3. AC Equipment Standard Rating Conditions $\left({ }^{\circ} \mathrm{C}\right)$

\begin{tabular}{|l|l|l|l|l|l|}
\hline Fluid & $\begin{array}{l}\text { Water- } \\
\text { cooled } \\
\text { water } \\
\text { chillers }\end{array}$ & $\begin{array}{l}\text { Air- } \\
\text { cooled } \\
\text { water } \\
\text { chillers }\end{array}$ & $\begin{array}{l}\text { Water- } \\
\text { cooled } \\
\text { unitary } \\
\text { AC }\end{array}$ & $\begin{array}{l}\text { Air- } \\
\text { cooled } \\
\text { unitary } \\
\text { AC }\end{array}$ & $\begin{array}{l}\text { Cooling } \\
\text { Towers }\end{array}$ \\
\hline Leaving chilled water & 6.7 & 6.7 & N/A & N/A & N/A \\
\hline Entering chilled water & 12.2 & 12.2 & N/A & N/A & N/A \\
\hline Leaving cooling water & 35.0 & N/A & 35.0 & N/A & 31.0 \\
\hline Entering cooling water & 29.4 & N/A & 29.4 & N/A & 36.5 \\
\hline Condenser air inlet & N/A & 35.0 & N/A & 35.0 & N/A \\
\hline Evaporator air inlet & N/A & N/A & $\begin{array}{l}27 \text { DB/ } \\
19.5 \text { WB }\end{array}$ & $\begin{array}{l}27 \text { DB/ } \\
19.5 ~ W B\end{array}$ & N/A \\
\hline Cooling tower air inlet & N/A & N/A & N/A & N/A & 27.0 WB \\
\hline
\end{tabular}

Table 3-4. Minimum Efficiencies for AC Equipment

\begin{tabular}{|c|c|c|}
\hline Equipment Type & Size & $\begin{array}{l}\text { Minimum COP } \\
\text { (full load) }\end{array}$ \\
\hline Air-Cooled Chiller & All & 2.8 \\
\hline $\begin{array}{l}\text { Reciprocating } \\
\text { Water-Cooled Chiller }\end{array}$ & All & 4.2 \\
\hline $\begin{array}{l}\text { Centrifugal Water-Cooled } \\
\text { Chiller }\end{array}$ & All & 5.4 \\
\hline $\begin{array}{l}\text { Rotary Screw/Scroll Water- } \\
\text { Cooled Chiller }\end{array}$ & All & 4.4 \\
\hline $\begin{array}{l}\text { Unitary Air-Cooled Air } \\
\text { Conditioners }\end{array}$ & All & 2.4 \\
\hline $\begin{array}{l}\text { Unitary Water-Cooled Air } \\
\text { Conditioners }\end{array}$ & All & 4.0 \\
\hline Cooling Towers & All & $3.5 \mathrm{~L} / \mathrm{s} / \mathrm{kW}^{\mathrm{b}}$ \\
\hline
\end{tabular}

3.11.2 Excessive compressor cycling at part-load conditions shall not be controlled by either hot gas bypass or other evaporator pressure regulator control systems unless the system is designed with multiple steps of unloading. The capacity of the hot gas bypass shall be limited to not more than $50 \%$ of the total capacity in systems up to $70 \mathrm{~kW}$ of rated capacity, and to not more than $25 \%$ of the total capacity in systems over $70 \mathrm{~kW}$ of rated capacity.

3.11.3 Water-to-water heat recovery systems (double-bundle chillers) should be used for water heating only after carrying out an energy balance, cost-benefit analysis and lifecycle costing. Such systems to produce hot water at temperatures exceeding $42^{\circ} \mathrm{C}$ are discouraged.

3.11.4 Designers are encouraged to consider cooling towers with 2-speed or variablespeed fans, which are often very cost-effective. 


\subsection{Testing, Adjusting, Balancing and Commissioning}

3.12.1 Air system balancing shall be accomplished in a manner to minimise throttling losses and then fan speed shall be adjusted to meet design flow conditions.

3.12.2 Hydronic system balancing shall be accomplished in a manner to minimise throttling losses and then the pump impeller shall be trimmed or pump speed shall be adjusted to meet design flow conditions.

3.12.3 AC control systems shall be tested to assure that control elements are calibrated, adjusted, and in proper working condition.

3.12.4 Systems larger than $350 \mathrm{~kW}$ of cooling shall be commissioned in accordance with the procedures in ASHRAE Guideline1-1996, The HVAC Commissioning Process.

\subsection{Water Treatment}

3.13.1 The make-up water for systems larger than $350 \mathrm{~kW}$ of cooling shall be analyzed by a recognized authority to determine the chemical characteristics of the water. This procedure shall be repeated once within every 365 days from the date of the commissioning of the plant to verify whether the chemical characteristics have changed.

3.13.2 Appropriate water treatment equipment shall be specified and installed to minimize the possibility of corrosion to the water cooling circuits, scale formation, and biological growth as well as the presence of suspended solids and sludge formation. The reduction in the quantity of water to be bled from the water circuit shall also be addressed with the intent to reduce water usage and pumping energy costs.

3.13.3 Water treatment may be in the form of automatically dosing chemicals, magnetic de-scalers, filtration equipment, ozone dosing, or a combination of these methods.

3.13.4 Water treatment shall be in accordance with procedures detailed in ASHRAE 1995 HVAC Applications Handbook, Chapter 44 (Corrosion Control and Water Treatment), or other equivalent publications.

\subsection{Maintenance:}

(a) An operating and maintenance manual shall be provided to the owner. The manual shall include basic data relating to the operation and maintenance of AC systems and equipment, including but not limited to original copies of manufacturers' O \& M manuals for all pieces of equipment. Required routine maintenance actions shall be clearly identified. Where applicable, AC controls information such as diagrams, schematics, control sequence descriptions, and maintenance and calibration information shall be included.

(b) The owner should implement a preventive maintenance program and schedule periodic maintenance on all the critical items of the air-conditioning 
system such as compressors, cooling towers, pumps, condensers, air handlers, controls, filters, and piping.

\subsection{Submission Procedure}

3.15.1 Plans provided to the Building Owner by a Chartered Engineer with adequate experience in the field of refrigeration and air-conditioning or a Full Member of ASHRAE shall contain the following:

(a) The cooling capacity in kW of each air-handling unit and air-conditioning plant.

(b) The capacity in L/s of each fan.

(c) The location and capacity of each fresh air intake.

(d) Supply, exhaust and return duct work distinctly coloured for clarity.

(e) A summary of the air-conditioning load calculations and equipment performance figures. 


\section{Building Envelope}

4.1 General Principles of Energy Efficient Envelope Design. Solar heat gain through building envelope constitutes a substantial share of the cooling load in a building that will have to be eventually removed by the air-conditioning system at the expense of energy and utility bills. To minimize solar heat gain into a building is, therefore, a primary consideration in the design of energy-efficient buildings in Sri Lanka. Among the architectural techniques for achieving this are siting and orientation of rectangular buildings to avoid exposure of long axis to east and west, use of light colored exterior wall and roof surfaces, appropriate shading of fenestration, and employing moderate glass window areas. Opaque wall sections and roofs should incorporate thermal insulation materials to minimize heat gains. Air leakage through the building envelope into or from conditioned space should be minimized.

\subsection{System Performance Criteria for Exterior Walls}

4.2.1 The total Overall Thermal Transfer Value (OTTV) for the exterior walls of a building shall not exceed $90 \mathrm{~W} / \mathrm{m}^{2}$. OTTV is a system performance criterion that allows trade-offs among opaque wall and window areas and their thermal and solar characteristics to achieve an overall minimum performance. OTTV is calculated for each individual façade and then for the building taking the weighted average of the individual façade OTTVs.

4.2.2 OTTV for an individual façade is calculated using following formula:

$$
\mathrm{OTTV}_{\mathrm{i}}=\mathrm{TD}_{\mathrm{EQ}} \forall(1-W W R) \mathrm{U}_{\mathrm{W}}+\Delta \mathrm{T}(\mathrm{WWR}) \mathrm{U}_{\mathrm{F}}+\mathrm{SF} \text { (WWR) SC CF }
$$

Where the terms are defined as:

$\operatorname{OTTV}_{i}=$ overall thermal transmittance value for the $i^{\text {th }}$ specific wall orientation and construction combination, $\left(\mathrm{W} / \mathrm{m}^{2}\right)$

$\mathrm{TD}_{\mathrm{EQ}}=$ equivalent indoor-outdoor temperature difference through the opaque wall section, $\left(19.3^{\circ} \mathrm{C}\right)$

$\forall \quad=$ = solar absorptance of the exterior opaque wall (dimensionless)

WWR = window-to-wall ratio, using the gross wall area in the denominator, (dimensionless).

$U_{\mathrm{W}} \quad=$ thermal transmittance of opaque wall section, $\left(\mathrm{W} / \mathrm{m}^{2 \circ} \mathrm{C}\right)$

$\mathrm{T} \quad=$ temperature difference through the window section, $\left(3.6^{\circ} \mathrm{C}\right)$

$\mathrm{U}_{\mathrm{F}} \quad=$ thermal transmittance of window section, $\left(\mathrm{W} / \mathrm{m}^{2 \circ} \mathrm{C}\right)$

$\mathrm{SF} \quad=$ solar factor, defined as the average hourly value of solar energy incident on vertical windows, $\left(186 \mathrm{~W} / \mathrm{m}^{2}\right)$

$\mathrm{SC} \quad=$ shading coefficient of the fenestration system as given in Section 4.3, (dimensionless)

$\mathrm{CF} \quad=$ solar correction factor for the orientation of the fenestration as given in Table 4-1, dimensionless

Replacing the constants suitable for Sri Lanka into Equation 4-1 above,

OTTV $_{i}=19.3 \forall(1-W W R) U_{W}+3.6 W W R R_{F}+186 W W R$ SC CF 
Table 4-1. Solar Correction Factors (CF) (dimensionless)

\begin{tabular}{|c|c|c|c|c|c|c|c|}
\hline South & North & East & West & SE & NE & SW & NW \\
\hline 0.95 & 0.79 & 1.34 & 0.90 & 1.15 & 1.07 & 0.93 & 0.85 \\
\hline
\end{tabular}

4.2.3 The OTTV for the total exterior gross wall area of the building is a weighted average of the OTTV's computed for the individual façades. For a building with $\mathrm{N}$ individual façades, OTTV shall be determined by:

$$
\text { OTTV }=\frac{\left(A_{1} \text { OTTV }_{1}+A_{2} \text { OTTV }_{2}+\ldots+A_{N} \text { OTTV }_{N}\right)}{\left(A_{1}+A_{2}+\ldots+A_{N}\right)} \quad \text { Eq (4-3) }
$$

\subsection{Shading Coefficient}

4.3.1 Shading coefficient is defined as the ratio of the solar heat gain through the fenestration system under consideration to the solar heat gain through an unshaded clear $3 \mathrm{~mm}$ thick glass. The fenestration system is defined as the combination of glazing and any external shading devices affixed to the building.

$$
S C=\frac{\text { solar heat gain of fenestration system }}{\text { solar heat gain of unshaded clear } 3 \mathrm{~mm} \text { glass }}
$$

In general, the SC of the fenestration system is the product of the SC of the glass and the SC of the external shading device.

$$
\mathrm{SC}=\mathrm{SC}_{\text {glass }} \mathrm{SC}_{\text {shade }} \quad \mathrm{Eq}(4-5)
$$

4.3.2 SC for glass shall be based on manufacturers' recommended value at an incidence angle of 45 degrees.

4.3.3 SC for external shading projections (e.g., horizontal, vertical, eggcrate) shall be determined from Tables 4-2 through 4-4 (or its closest approximation), where R1 is the ratio of the horizontal projection depth to the window height and $\mathrm{R} 2$ is the ratio of the vertical projection depth to the window width. Any distance between the top of the window and the bottom of the horizontal projection should be added to the window height in calculating R1. Any distance between the sides of the window and the fin projections (on both sides if applicable) should be added to the window width in calculating R2. 


$$
\begin{array}{lll}
R 1=\quad \text { depth of horizontal projection } & \\
\text { height of window } & \text { Eq (4-6) } \\
\text { R2 } \quad \text { depth of vertical projection } & \\
\hdashline \text { width of window } & \text { Eq (4-7) }
\end{array}
$$

Table 4-2. Shading Coefficient (SC) for Horizontal Overhang Projections

\begin{tabular}{|c|c|c|c|c|c|c|c|c|}
\hline & \multicolumn{9}{|c|}{ Orientation } \\
\hline R1 & South & North & East & West & SE & NE & SW & NW \\
\hline 0.2 & 0.69 & 0.77 & 0.80 & 0.76 & 0.75 & 0.79 & 0.72 & 0.76 \\
\hline 0.4 & 0.53 & 0.68 & 0.68 & 0.59 & 0.61 & 0.68 & 0.56 & 0.64 \\
\hline 0.6 & 0.45 & 0.63 & 0.58 & 0.50 & 0.52 & 0.61 & 0.47 & 0.56 \\
\hline 0.8 & 0.39 & 0.59 & 0.50 & 0.43 & 0.45 & 0.54 & 0.41 & 0.51 \\
\hline 1.0 & 0.37 & 0.56 & 0.43 & 0.40 & 0.40 & 0.50 & 0.38 & 0.48 \\
\hline 1.2 & 0.36 & 0.54 & 0.39 & 0.37 & 0.37 & 0.46 & 0.36 & 0.46 \\
\hline 1.4 & 0.35 & 0.53 & 0.35 & 0.36 & 0.35 & 0.44 & 0.35 & 0.44 \\
\hline 1.6 & 0.34 & 0.52 & 0.32 & 0.35 & 0.33 & 0.42 & 0.34 & 0.43 \\
\hline 1.8 & 0.33 & 0.51 & 0.29 & 0.34 & 0.31 & 0.40 & 0.34 & 0.42 \\
\hline 2.0 & 0.33 & 0.50 & 0.27 & 0.33 & 0.30 & 0.38 & 0.33 & 0.42 \\
\hline
\end{tabular}

Table 4-3. Shading Coefficient (SC) for Vertical Side-Fin Projections

\begin{tabular}{|c|c|c|c|c|c|c|c|c|}
\hline & \multicolumn{9}{|c|}{ Orientation } \\
\hline R2 & South & North & East & West & SE & NE & SW & NW \\
\hline 0.2 & 0.80 & 0.80 & 0.87 & 0.84 & 0.83 & 0.83 & 0.82 & 0.82 \\
\hline 0.4 & 0.75 & 0.75 & 0.83 & 0.79 & 0.79 & 0.79 & 0.77 & 0.77 \\
\hline 0.6 & 0.71 & 0.70 & 0.79 & 0.75 & 0.75 & 0.75 & 0.73 & 0.73 \\
\hline 0.8 & 0.69 & 0.68 & 0.77 & 0.73 & 0.73 & 0.73 & 0.71 & 0.71 \\
\hline 1.0 & 0.67 & 0.66 & 0.75 & 0.71 & 0.71 & 0.71 & 0.69 & 0.68 \\
\hline 1.2 & 0.67 & 0.66 & 0.75 & 0.71 & 0.71 & 0.70 & 0.69 & 0.68 \\
\hline 1.4 & 0.66 & 0.64 & 0.74 & 0.70 & 0.70 & 0.69 & 0.68 & 0.67 \\
\hline 1.6 & 0.66 & 0.64 & 0.73 & 0.70 & 0.70 & 0.69 & 0.68 & 0.67 \\
\hline 1.8 & 0.66 & 0.64 & 0.73 & 0.69 & 0.69 & 0.68 & 0.67 & 0.67 \\
\hline 2.0 & 0.65 & 0.63 & 0.72 & 0.69 & 0.69 & 0.68 & 0.67 & 0.66 \\
\hline
\end{tabular}


Table 4-4. Shading Coefficient (SC) for Horizontal \& Vertical "Egg-Crate" Projections

\begin{tabular}{|c|c|c|c|c|c|c|c|c|c|}
\hline & & \multicolumn{9}{|c|}{ Orientation } \\
\hline R1 & R2 & South & North & East & West & SE & NE & SW & NW \\
\hline 0.2 & 0.2 & 0.52 & 0.60 & 0.72 & 0.62 & 0.62 & 0.66 & 0.57 & 0.61 \\
\hline 0.2 & 0.4 & 0.31 & 0.46 & 0.53 & 0.41 & 0.42 & 0.49 & 0.36 & 0.44 \\
\hline 0.2 & 0.6 & 0.21 & 0.36 & 0.40 & 0.27 & 0.31 & 0.38 & 0.24 & 0.32 \\
\hline 0.2 & 0.8 & 0.17 & 0.30 & 0.28 & 0.18 & 0.23 & 0.29 & 0.18 & 0.24 \\
\hline 0.2 & 1.0 & 0.13 & 0.25 & 0.18 & 0.13 & 0.15 & 0.22 & 0.13 & 0.19 \\
\hline 0.4 & 0.2 & 0.48 & 0.55 & 0.65 & 0.58 & 0.56 & 0.60 & 0.53 & 0.56 \\
\hline 0.4 & 0.4 & 0.27 & 0.42 & 0.50 & 0.37 & 0.38 & 0.46 & 0.32 & 0.39 \\
\hline 0.4 & 0.6 & 0.20 & 0.34 & 0.37 & 0.25 & 0.28 & 0.36 & 0.23 & 0.30 \\
\hline 0.4 & 0.8 & 0.15 & 0.28 & 0.26 & 0.16 & 0.20 & 0.27 & 0.15 & 0.22 \\
\hline 0.4 & 1.0 & 0.22 & 0.37 & 0.30 & 0.23 & 0.26 & 0.34 & 0.23 & 0.30 \\
\hline 0.6 & 0.2 & 0.43 & 0.50 & 0.62 & 0.53 & 0.53 & 0.56 & 0.48 & 0.52 \\
\hline 0.6 & 0.4 & 0.25 & 0.40 & 0.47 & 0.35 & 0.36 & 0.43 & 0.30 & 0.37 \\
\hline 0.6 & 0.6 & 0.18 & 0.31 & 0.35 & 0.23 & 0.26 & 0.33 & 0.20 & 0.27 \\
\hline 0.6 & 0.8 & 0.24 & 0.39 & 0.34 & 0.26 & 0.29 & 0.37 & 0.25 & 0.32 \\
\hline 0.6 & 1.0 & 0.18 & 0.32 & 0.23 & 0.19 & 0.21 & 0.28 & 0.19 & 0.26 \\
\hline 0.8 & 0.2 & 0.42 & 0.48 & 0.60 & 0.52 & 0.51 & 0.54 & 0.47 & 0.50 \\
\hline 0.8 & 0.4 & 0.23 & 0.37 & 0.44 & 0.33 & 0.34 & 0.41 & 0.28 & 0.35 \\
\hline 0.8 & 0.6 & 0.26 & 0.42 & 0.41 & 0.28 & 0.34 & 0.42 & 0.27 & 0.35 \\
\hline 0.8 & 0.8 & 0.20 & 0.34 & 0.28 & 0.21 & 0.24 & 0.31 & 0.21 & 0.28 \\
\hline 0.8 & 1.0 & 0.15 & 0.27 & 0.20 & 0.15 & 0.17 & 0.24 & 0.15 & 0.21 \\
\hline 1.0 & 0.2 & 0.40 & 0.45 & 0.58 & 0.49 & 0.49 & 0.52 & 0.44 & 0.47 \\
\hline 1.0 & 0.4 & 0.29 & 0.46 & 0.50 & 0.35 & 0.39 & 0.48 & 0.32 & 0.40 \\
\hline 1.0 & 0.6 & 0.22 & 0.37 & 0.35 & 0.24 & 0.28 & 0.36 & 0.23 & 0.31 \\
\hline 1.0 & 0.8 & 0.16 & 0.29 & 0.24 & 0.17 & 0.20 & 0.27 & 0.17 & 0.23 \\
\hline 1.0 & 1.0 & 0.13 & 0.25 & 0.17 & 0.13 & 0.15 & 0.21 & 0.13 & 0.19 \\
\hline 1.2 & 0.2 & 0.36 & 0.51 & 0.60 & 0.45 & 0.48 & 0.55 & 0.41 & 0.48 \\
\hline 1.2 & 0.4 & 0.25 & 0.41 & 0.43 & 0.31 & 0.34 & 0.42 & 0.28 & 0.36 \\
\hline 1.2 & 0.6 & 0.18 & 0.32 & 0.32 & 0.20 & 0.25 & 0.32 & 0.19 & 0.26 \\
\hline 1.2 & 0.8 & 0.15 & 0.28 & 0.21 & 0.16 & 0.18 & 0.24 & 0.15 & 0.22 \\
\hline 1.2 & 1.0 & 0.11 & 0.22 & 0.13 & 0.11 & 0.12 & 0.18 & 0.11 & 0.17 \\
\hline
\end{tabular}

\subsection{Roofs}

4.4.1 The maximum allowable thermal transmittance $\left(U\right.$-value in $\mathrm{W} / \mathrm{m}^{2}-{ }^{\circ} \mathrm{C}$ ) of the roof assembly is shown in Table 4-5, which is a function of the weight of construction materials of the roof assembly in $\mathrm{kg} / \mathrm{m}^{2}$ and external surface color. For purposes of this document, the roof assembly includes only the horizontal elements, not the structural or vertical elements. 
Table 4-5. Maximum U-Value for Roofs $\left(\mathrm{W} / \mathrm{m}^{2}-^{\circ} \mathrm{C}\right)$

\begin{tabular}{|l|c|c|}
\hline Exterior Roof Surface & \multicolumn{2}{|c|}{ Roof Assembly Mass } \\
\cline { 2 - 3 } Solar Absorptance $(\forall)$ & $\leq \mathbf{1 0 0} \mathbf{~ k g} / \mathbf{m}^{\mathbf{2}}$ & $\mathbf{> 1 0 0} \mathbf{~ k g} / \mathbf{m}^{\mathbf{2}}$ \\
\hline Light $(\forall<0.4)$ & 0.7 & 1.5 \\
\hline Medium $(0.4<\forall<0.6)$ & 0.3 & 0.5 \\
\hline Dark $(\forall>0.6)$ & 0.2 & 0.3 \\
\hline
\end{tabular}

\subsection{Air Leakage}

4.5.1 The requirements of this section are limited to those building elements separating exterior ambient conditions from interior building conditioned air space.

4.5.2 The following areas of the building envelope shall be sealed, caulked, gasketed, or weather-stripped to minimize air leakage:

(a) joints around fenestration and doors

(b) junctions between walls and foundations, between walls at building corners, between walls and structural floors or roofs, and between walls and roof or wall panels

(c) openings at penetrations of utility services through roofs, walls, and floors

(d) site built fenestration and doors

(e) building assemblies used as ducts or plenums

(f) joints, seams, and penetrations of vapor retarders

(g) all other openings in the building envelope

4.5.3 Fenestration and doors shall be designed to limit air leakage such that the air infiltration rate not exceed $5.0 \mathrm{~L} / \mathrm{s} \mathrm{m}^{2}$ for glazed swinging entrance doors and for revolving doors, and $2.0 \mathrm{~L} / \mathrm{s} \mathrm{m}^{2}$ for all other fenestration and door products.

\subsection{Submission Procedure}

4.6.1 The following shall be provided to the building owner by the engineer or architect:

(a) OTTV calculations for the exterior walls and supporting data and drawings

(b) U-value calculations for the roof and supporting data and drawings

(c) Plan to minimize air leakage and supporting data 


\section{Electric Power and Distribution}

\subsection{Scope}

5.1.1 This section applies to all building electrical systems, except required extra low voltage systems, if wired separately.

5.1.2 The following sub-sections address only energy-efficiency issues and not other aspects of design, installation, operation, and maintenance of building electrical power and distribution systems.

5.1.3 For existing buildings at the stage of rewiring, all criteria under 5.2 should apply.

\subsection{Electrical Distribution System}

5.2.1 Supply connection exceeding $1000 \mathrm{kVA}$ shall have built-in recording facility to record demand (kVA), energy consumption (kWh), and total power factor in permanently installed energy meter. The metering shall also display current ( $A$ in each phase and the neutral), voltage ( $V$ between phases and between each phase and neutral), and total harmonic distortion (THD of current) as a percentage of total current.

5.2.2 Supply connection not exceeding 1000 kVA but over 125 kVA shall have built-in recording facility to record demand (kVA), energy consumption (kWh), and total power factor.

5.2.3 Supply connection not exceeding $125 \mathrm{kVA}$ shall have built-in recording facility to record energy consumption (kWh).

5.2.4 Check Metering. Buildings whose maximum demand is greater than $250 \mathrm{kVA}$ shall have the electrical distribution system designed so that energy consumption can be check-metered. The electrical power feeders for each facility for which check-metering is required shall be subdivided in accordance with the following categories:

(a) Lighting and socket outlets.

(b) Air-conditioning systems and equipment.

(c) Other load centers with probable high energy consumption, such as kitchen, laundry, and restaurants in hotels or surgery rooms in hospitals.

5.2.5 Tenant Submetering. Multiple-Tenant Buildings shall have submetering for each tenant. Each tenant having a maximum demand of $100 \mathrm{kVA}$ or more shall have provision to permit check-metering the tenant load as per 5.2.4 above. Common airconditioning systems need not meet these tenant check-metering requirements.

5.2.6 Additional Metering. The designer and user should consider additional metering where it would be useful for analysis to improve efficiency in the end-use loads and the distribution systems serving them.

5.2.7 Power Factor Correction. All electricity supplies exceeding 100 A, 3 phase shall maintain their power factor between 0.98 lag and unity at the point of connection. Loads should have power factor correction at the point of use (capacitors on motors and 
lighting fixtures with ballasts; harmonic filters on non-linear loads); if necessary further correction equipment at the main switchboard should be provided to meet the overall requirement.

5.2.8 Neutral Current. Building loads should be balanced such that the fundamental component of the neutral current in any three-phase installation does not exceed $10 \%$ of the design current of the entire installation when the design current is being supplied.

5.2.9 Conductor Sizing. Every effort should be made to size electrical conductors so as to minimize life-cycle costs. Designers may use British Standard 7450 (Method of Determination of Economic Optimization of Power Cable Size) for guidance.

\subsection{Transformers}

5.3.1 All transformers that are part of the building electrical distribution system should be selected to minimise the combination of no-load, part-load, and full-load losses, without compromising the electrical system operation and reliability requirements.

5.3.2 If the total capacity of such transformers exceeds $250 \mathrm{kVA}$, a calculation of total estimated annual operating costs of the transformer losses shall be made and compared to the cost of more-efficient transformers. This calculation shall be based on estimated hours of transformer operation at projected loading conditions, and the associated transformer losses. Based on this analysis, transformer(s) with the lowest life-cycle cost shall be selected.

5.3.3 Three-phase oil-immersed transformers shall be selected based on maximum allowable losses in Table 5-1 and 5-2.

\subsubsection{Exceptions:}

(a) Transformers below $100 \mathrm{kVA}$ and above $1000 \mathrm{kVA}$

(b) AC and DC drive transformers

(c) All rectifier transformers and transformers designed for higher harmonics

(d) Autotransformers

(e) Non-distribution transformers, such as UPS (Uninterruptible Power supply) transformers

(f) Special impedence transformers applied for special cases.

(g) Grounding or testing transformers. 
Table 5-1. $11 \mathrm{kV}$ Transformer, 3-phase, oil immersed

\begin{tabular}{|c|c|}
\hline Transformer Capacity, kVA & $\begin{array}{l}\text { Maximum Allowable Losses at Full } \\
\text { Load (\% load loss + no-load loss) }\end{array}$ \\
\hline 100 & 2.5 \\
\hline 160 & 2.3 \\
\hline 250 & 2.1 \\
\hline 400 & 1.5 \\
\hline 630 & 1.4 \\
\hline 800 & 1.4 \\
\hline 1000 & 1.2 \\
\hline \multicolumn{2}{|c|}{ Reference conditions: $100 \%$ of nameplate load at temperature of $75^{\circ} \mathrm{C}}$. \\
\hline
\end{tabular}

Table 5-2. 33 kV Transformer, 3-phase, oil immersed

\begin{tabular}{|c|c|}
\hline Transformer Capacity, kVA & $\begin{array}{l}\text { Maximum Allowable Losses at Full } \\
\text { Load (\% load loss + no-load loss) }\end{array}$ \\
\hline 100 & 2.7 \\
\hline 160 & 2.2 \\
\hline 250 & 1.8 \\
\hline 400 & 1.5 \\
\hline 630 & 1.5 \\
\hline 800 & 1.5 \\
\hline 1000 & 1.2 \\
\hline \multicolumn{2}{|c|}{ Reference conditions: $100 \%$ of nameplate load at temperature of $75^{\circ} \mathrm{C}$. } \\
\hline
\end{tabular}

5.4 Electric Motors. All permanently wired electric motors that serve the building shall meet the requirements of this Section.

5.4.1 Three-phase induction motors shall have a nominal full-load motor efficiency not less than shown as "Required" in Table 5-3.

5.4.2 System designers should select motors to minimize the life-cycle cost of the motordriven system. Such analysis will often result in the use of motors of a higher efficiency than required herein. The "Recommended" efficiencies in Table 5-3 provide a suggested improved efficiency level for motor selection. Designers should perform a life-cycle cost analysis to select the proper motor.

5.4.3 Motor types and sizes not covered by Table 5-3 are not regulated as to efficiency by this section. However, designers should also use highly efficient motors for other categories not specifically covered by this standard. Such categories include smaller and larger polyphase motors, polyphase motors of 6 and 8 poles, and single-phase motors.

5.4.4 Motor nameplates shall list the minimum and the nominal full-load motor efficiencies and the full-load power factor. 
5.4.5 Motor horsepower rating shall not exceed $200 \%$ of the calculated maximum load being served.

5.4.6 Motor Rewinding. Motor users should insist on proper rewinding practices for any rewound motors. If the following practices cannot be assured, the damaged motor should be replaced with a new, efficient one rather than suffer the significant efficiency penalty associated with typical rewind practices. At a minimum, the following practices (taken from "Guidelines for Maintaining Motor Efficiency During Rebuilding", Electrical Apparatus Service Association, St. Louis, MO, USA) should be followed for rewinding:

(a) Conduct a stator core loss test before and after stripping.

(b) Repair or replace defective laminations.

(c) Calibrate all test equipment and measuring devices at least annually against standards traceable to the National Standard.

(d) Measure and record winding resistance and room temperature.

(e) Measure and record no-load amps and voltage during the final test.

(f) Have a quality assurance program.

(g) Have and use, at a minimum, the following test equipment: ammeter, voltmeter, wattmeter, ohmmeter, megohmmeter, and high potential tester.

(h) Have a three-phase power supply for running motors at rated voltage.

(i) Balance the rotor.

(j) Do not heat stators above $350^{\circ} \mathrm{C}$.

(k) Do not sandblast the iron core.

(I) Do not knurl, peen, or paint bearing fits.

(m) Do not use an open flame for stripping.

(n) Do not grind the laminations or file the slots.

(o) Do not increase the air gap.

(p) Do not increase the resistance of the windings.

(q) Do not make mechanical modifications without the customer's prior approval. This includes but is not limited to changing fans, types of bearings, shaft material, and seals.

(r) Do not change the winding design. 
Table 5-3. Minimum Efficiencies for Three-Phase Induction Motors

\begin{tabular}{|c|c|c|c|c|}
\hline $\begin{array}{l}\text { Motor } \\
\text { Output }\end{array}$ & \multicolumn{2}{|c|}{$\begin{array}{l}\text { Required } \\
\text { Efficiency (\%) }\end{array}$} & \multicolumn{2}{|c|}{$\begin{array}{l}\text { Recommended } \\
\text { Efficiency (\%) }\end{array}$} \\
\hline $\mathrm{KW}$ & 2 Pole & 4 Pole & 2 Pole & 4 Pole \\
\hline 1.1 & 82.2 & 83.8 & 85.5 & 86.5 \\
\hline 1.5 & 84.1 & 85.0 & 86.5 & 86.5 \\
\hline 2.2 & 85.6 & 86.4 & 86.5 & 89.5 \\
\hline 3.0 & 86.7 & 87.4 & 87.2 & 89.5 \\
\hline 4.0 & 87.6 & 88.3 & 89.5 & 89.5 \\
\hline 5.5 & 88.5 & 89.2 & 89.5 & 91.0 \\
\hline 7.5 & 89.5 & 90.1 & 90.2 & 91.7 \\
\hline 11.0 & 90.6 & 91.0 & 91.0 & 93.0 \\
\hline 15.0 & 91.3 & 91.8 & 92.4 & 93.0 \\
\hline 18.5 & 91.8 & 92.2 & 93.0 & 93.6 \\
\hline 22.0 & 92.2 & 92.6 & 93.0 & 94.1 \\
\hline 30.0 & 92.9 & 93.2 & 93.6 & 94.1 \\
\hline 37.0 & 93.3 & 93.6 & 93.6 & 94.5 \\
\hline 45.0 & 93.7 & 93.9 & 94.1 & 95.0 \\
\hline 55.0 & 94.0 & 94.2 & 94.5 & 95.0 \\
\hline 75.0 & 94.6 & 94.7 & 95.0 & 95.4 \\
\hline
\end{tabular}

5.5 Submission Procedure. Building owners shall be provided with written information that provides basic data relating to the design, operation, and maintenance of the electrical distribution system for the building. This shall include:

(a) A single-line diagram of the building electrical system, inclusive of all the metering equipment.

(b) Floor plans showing locations of equipment, distributing gear, power factor correction equipment, and metering equipment.

(c) Schematic diagrams of electrical control systems used for power saving (if any).

(d) Manufactures data sheets as to confirm the maximum losses allowed by the clause 5.3 .3 (applicable only for consumers) \& for motors by the clause 5.4.1. 


\section{Service Water Heating}

\subsection{Scope}

6.1.1 This section applies to all service water heating systems and equipment.

6.1.2 The following sub-sections address only energy-efficiency issues and not other aspects of design, installation, operation, and maintenance of service water heating systems.

\subsection{Sizing of Systems}

6.2.1 Service water heating system design loads for the purpose of sizing systems and equipment shall follow manufacturers' recommendations.

\subsection{Water Heating Equipment Efficiency}

6.3.1 All water heating equipment, hot water supply boilers used solely for heating potable water, pool heaters, and hot water storage tanks shall meet the criteria listing in Table 6-1.

6.3.2 Electric resistance water heaters are strongly discouraged except as backup for other SHW systems. Electric heat pump water heaters have considerably higher energy efficiency than electric resistance water heaters, particularly in Sri Lankan climate conditions.

6.3.3 Efficiency for electric resistance water heaters is given in terms of maximum Standby Loss (SL), where $V$ is the measured volume in liters. $\mathrm{SL}$ is the maximum watts based on a $38.9^{\circ} \mathrm{C}$ temperature difference between stored water and ambient requirements.

6.3.4 Minimum efficiency for oil \& gas-fired water heaters is given in terms of Thermal Efficiency $\left(E_{T}\right)$, which includes thermal losses from the heater shell.

Table 6-1. Minimum Energy Efficiency of Water Heating Equipment

\begin{tabular}{|l|c|}
\hline Equipment Type & Minimum Efficiency \\
\hline Electric Resistance Water Heaters & $5.9+5.3 \mathrm{VL}$ (W) \\
\hline Gas Storage Water Heaters & $78 \% \mathrm{E}_{\mathrm{T}}$ \\
\hline Gas Instantaneous Water Heaters & $78 \% \mathrm{E}_{\mathrm{T}}$ \\
\hline Gas Hot Water Supply Boilers & $77 \% \mathrm{E}_{\mathrm{T}}$ \\
\hline Oil Hot Water Supply Boilers & $80 \% \mathrm{E}_{\mathrm{T}}$ \\
\hline Dual Fuel Gas/Oil Hot Water Supply Boilers & $80 \% \mathrm{E}_{\mathrm{T}}$ \\
\hline
\end{tabular}

6.3.5 Where appropriate, solar water heating systems should be considered to supply all or part of service hot water demand. Solar water heaters shall have a minimum 
efficiency of $60 \%$ and have a minimum insulation R-value of $2.2\left(\left(\mathrm{~m}^{2}-{ }^{\circ} \mathrm{C}\right) / \mathrm{W}\right)$ behind the collector plate.

\subsection{Service Water Heating Piping Insulation}

6.4.1 The following hot water piping shall be insulated to levels shown in Table 6-2.

(a) Recirculating system piping, including the supply and return piping of a circulating tank type water heater

(b) The first 2.4 meters of outlet pipting for a constant temperature nonrecirculating storage system

(c) The inlet pipe between the storage tank and a heat trap in a nonrecirculating storage system

(d) Pipes that are externally heated

Table 6-2. Minimum Pipe Insulation Thickness (cm)

\begin{tabular}{|l|l|l|c|c|}
\hline \multirow{2}{*}{$\begin{array}{l}\text { Fluid Design } \\
\text { Operating } \\
\begin{array}{l}\text { Temp. Range } \\
\left({ }^{\circ} \mathrm{C}\right)\end{array}\end{array}$} & $\begin{array}{l}|c| \\
\text { Insulation Conductivity }\end{array}$ & \multicolumn{2}{c|}{ Nominal Pipe Size } \\
\hline \multicolumn{1}{|c|}{$\begin{array}{l}\text { Conductivity } \\
\left(\mathrm{W} / \mathrm{m}-{ }^{\circ} \mathrm{C}\right)\end{array}$} & $\begin{array}{l}\text { Mean Rating } \\
\text { Temp. }\left({ }^{\circ} \mathrm{C}\right)\end{array}$ & $<25 \mathrm{~mm}$ & $\geq 25 \mathrm{~mm}$ \\
\hline 41 & $0.032-0.040$ & 38 & 1.3 & 2.5 \\
\hline
\end{tabular}

6.4.2 For insulation outside the stated conductivity range, the minimum thickness $(T)$ shall be determined with the following formula:

$$
T=r\left[(1+t / r)^{K / k}-1\right]
$$

where,

$$
\begin{aligned}
& T=\text { minimum thickness }(\mathrm{cm}) \\
& R=\text { actual outside radius of pipe }(\mathrm{cm}) \\
& t=\text { insulation thickness listed in Table } 6-2 \text { for applicable pipe size } \\
& K=\text { conductivity of alternate material at mean } 38^{\circ} \mathrm{C} \text { mean rating temp. } \\
& \mathrm{K}=0.040
\end{aligned}
$$

\subsection{Service Water Heating System Controls}

6.5.1 Temperature controls shall be provided to limit point-of-use water temperatures not to exceed $50^{\circ} \mathrm{C}$.

6.5.2 Temperature controls shall be provided to limit the maximum temperature of water delivered to wash basin faucets in public restrooms to $43^{\circ} \mathrm{C}$.

6.5.3 Systems designed to maintain usage temperatures in hot water pipes, such as recirculating hot water systems, shall be equipped with automatic time switches or other 
controls that can be set to switch off the usage temperature maintenance system during extended periods when hot water is not required.

6.5.4 When used to maintain storage tank water temperature, recirculating pumps shall be equipped with controls limiting operation to a period from the start of the heating cycle to a maximum of 5 minutes after the end of the heating cycle.

\subsection{Heat Traps}

6.6.1 Vertical pipe risers serving storage water heaters and storage tanks not having integral heat traps and serving a nonrecirculating system shall have heat traps on both the inlet and outlet piping as close as practical to the storage tank. A heat trap is a means to counteract the natural convection of heated water in a vertical pipe run. The means is either a device specifically designed for the purpose or an arrangement of tubing that forms a loop of 360 degrees or piping that from the point of connection to the water heater (inlet or outlet) includes a length of piping directed downward before connection to the vertical piping of the supply water or hot water distribution system, as applicable.

\subsection{Submission Procedure}

6.7.1 The Engineer responsible for the service hot water system installation shall provide complete details to the Building Owner including the following information:

(a) Input energy consumption rate $(\mathrm{kW} / \mathrm{kcal})$

(b) Design operating temperature range

(c) For boilers, maximum design pressure, tested pressure $(\mathrm{Pa})$

(d) Type of fuel is used

(e) Listing of equipment

(f) Storage tank capacity (liters)

(g) Maximum draw off rate (liters/sec) 